
Determination of IL-35, PTH, Ferritin and Other biochemical. Parameters in sera of Iraqi Men with chronic kidney failure

Rasha Zuhair Jasim and Samira Muajed Yaseen

\title{
Determination of IL-35, PTH, Ferritin and Other biochemical. Parameters in sera of Iraqi Men with chronic kidney failure
}

\author{
Rasha Zuhair Jasim and Samira Muajed Yaseen \\ College of Education for pure sciences (Ibn Al-Haitham)-Baghdad University \\ Received 4 April 2016; Accepted 16 August 2016
}

\begin{abstract}
Chronic kidney Failure, a progressive disease, includes both medical and biochemical features that damage kidneys and decrease their abilities to work effectively, this disease is characterized by a chronic disorders to both the innate and adaptive immune systems, generate a complex and not fully understood immune dysfunction. In the present study, (30) men suffering from chronic kidney failure with age in range (40-55) year and (30) healthy men within the same range of age were enrolled in this study. The aim of this study is to highlight the role of immunological aspect (IL-35), hormonal aspects (PTH), some functional proteins and immunological electrolytes in sera of chronic kidney failure (CKF) patients. Biochemical parameters were determined in the sera of both patients and (healthy) control group. Patients enrolled in this study were newly diagnosed, they have not taken any treatment related to any chronic disease. Blood samples were collected and biochemical parameters were measured in Al- Karama teaching hospital in Baghdad (except IL-35 which was determined in the private Al-Ghazalia Laboratory) from April to November 2015. Results have reported that IL-35 level was highly significant increase in sera of chronic kidney failure patients $(35.035 \pm 0.025) \mathrm{pg} / \mathrm{mL}$ compared with healthy group $(23.331 \pm 0.031) \mathrm{pg} / \mathrm{mL}$. As well, PTH level was highly significant increased in patients group $(235.032 \pm 3.841) \mathrm{pg} / \mathrm{ml}$ compared with healthy control group $(49.96 \pm 0.308) \mathrm{pg} / \mathrm{mL}$. Hemoglobin level was highly significant decreased $(9.696 \pm 0.056) \mathrm{g} / \mathrm{L}$ in patients with control group $(15.332 \pm 0.067) \mathrm{g} / \mathrm{dL}$.
\end{abstract}




\section{Determination of IL-35, PTH, Ferritin and Other biochemical. Parameters in sera of Iraqi Men with chronic kidney failure}

\section{Rasha Zuhair Jasim and Samira Muajed Yaseen}

Also, ferritin level was highly significant decreased in chronic kidney failure patients (164.0.68 \pm 7.818$) \mathrm{ng} / \mathrm{mL}$ compared with control group $(313.56 \pm 1.874) \mathrm{ng} / \mathrm{mL}$. Moreover, albumin level was highly significant decreased $(3.00 \pm 0.020) \mathrm{g} / \mathrm{dL}$ in patients compared with control group $(4.928 \pm 0.039) \mathrm{g} / \mathrm{dL}$. Bicarbonate level was highly significant decreased $(17.412 \pm 0.117) \mathrm{mmol} / \mathrm{L}$ in patients compared with control group $(25.044 \pm 0.072) \mathrm{mmol} / \mathrm{L}$, sodium level was non significantly increased in patients $(138.65 \pm 0.288) \mathrm{meq} / \mathrm{L}$ compared with control group $(135.84 \pm 0.144)$ meq/L, potassium level was highly significant increased in patients group $(5.420 \pm 0.0186) \mathrm{meq} / \mathrm{L}$ compared with healthy control group $(4.700 \pm 0.113) \mathrm{meq} / \mathrm{L}$, calcium level was highly significant decreased in patients (7.464 \pm 0.054$) \mathrm{mmol} / \mathrm{L}$ compared with control group $(9.628 \pm 0.614) \mathrm{mmol} / \mathrm{L}$, phosphate level was significantly increased in patients $(4.891 \pm 0.016) \mathrm{mg} / \mathrm{dL}$ compared with control group $(4.552 \pm 0.014) \mathrm{mg} / \mathrm{dL}$. The present study concludes that IL-35 is a strong biochemical marker for Iraqi men with CKF. Moreover, this study indicated the positive relationship between $\left(\mathrm{PTH}, \mathrm{Na}^{+}, \mathrm{K}^{+}, \mathrm{PO}_{4}{ }^{2-}\right.$ ) and chronic kidney failure, and the negative relationship between (Ferritin, albumin, hemoglobin, $\mathrm{HCO}_{3}^{-}$) and chronic kidney failure in Iraq.

Keywords: Chronic kidney failure, IL-35, PTH, Ferritin. 


\title{
DIYALA JOURNAL FOR PURE SCIENCES
}

\section{Determination of IL-35, PTH, Ferritin and Other biochemical. Parameters in sera of Iraqi Men with chronic kidney failure}

\section{Rasha Zuhair Jasim and Samira Muajed Yaseen}

\author{
تقير مستويات الانترلوكين-35 وهرمون الباراثايرويد والفيرتين ومتغيرات كيموحيوية اخرى في \\ مصل دم رجال عراقيين مصابين بالفثل الكلوي المزمن \\ رشاز زهير جاسم و سميرة مؤيل ياسين \\ كلية التربية للعلوم الصرفة (ابن الهيثم) - جامعة بغداد
}

\section{الخلاصة}

يعد الفثل الكلوي المزمن أحد الأمراض المنقدمة التي تتضمن مظاهر طبية و كيموحيوية و التي بدور ها تقود إلى تدمير الكليتين و تقليل قدرتهما على العمل بكفاءة. إن هذا المرض ينصف بإضطر ابات مزمنة لكل من النظام المناعي الفطري و المكتسب ، مما يقود إلى إضطر اب معقد و غير مفهوم للجهاز المناعي. في هذه الدراسة، تم اشتراك (30) رجل مصابا بالفثل الكلوي المزمن ضمن الفئة العمرية (40-55) سنة و ثلاثون رجلا غير مصابا بأي مرض مزمن ضمن نفس الفئة العمرية. ان الهدف من الدراسة هو تسلبط الضوء على الجانب المناعي المتمثل بالانترلوكين-35 والجانب الهرموني بني المتمثل بهرمون البار اثايرويد وكذللك بعض البروتينات ذات الخصائص الوظيفية و الاكتروليتات في مصل دم مرضى مصابين بالفشل الكلوي المزمن. ان المتغيرات الكيموحيوية تم تقدير ها في مصل كل من المجموعة المرضية ومجموعة السيطرة. إن عينات دم المجموعة المرضية تعود إلى مرضى حديثي التشخيص بالفشل الكلوي المزمن و لم يتعاطون أي علاج يتعلق بأي مرض مزمن. تم جمع عينات الدم و إجراء القياسات الكيموحيوية في مستشفى الكر امة التعليمي في بغداد ( بإستثناء الإنترلوكين-35 الذي نم قياسه في مختبر الغزالية الأهلي) و للفترة المحصورة مابين نيسان إلى تترين الثاني 2015 ـ أثنتت النتائج أن مستوى الانترلوكين-35 قد ارتفع بشكل معنوي عالي في مصل دم المرضى المصابين بالفشل

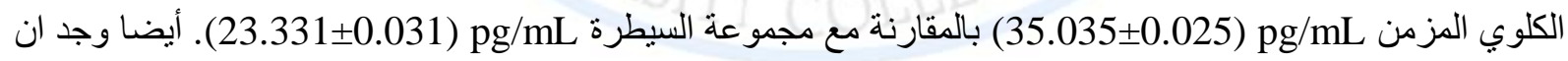
مستوى هرمون الباراثايرويد قد ازداد بشكل معنوي عالي لدى المجموعة المرضية pg/mL (235.023ـ3.841) بالمقارنة مع مجموعة السيطرة pg/ml (49.96×3.08) إن مستوى الهيموغلوبين قد انخفض بشكل معنوي عالي g/L g.696_0.056) في مصل دم المرضى المصابين بالفثل الكلوي المزمن بالمقارنة مع مجموعة السيطرة 16.332_0.067) g/L بالمقارنة مع مجموعة السيطرة ng/ml (313.56×1.874). فضلا عن ذلك وجد أن مستوى الالبومين قد انخفض بشكل

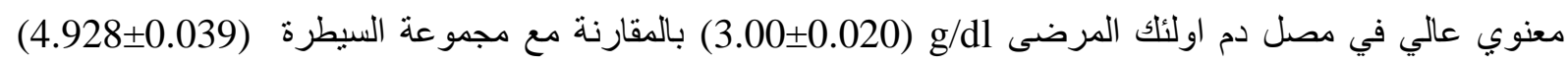

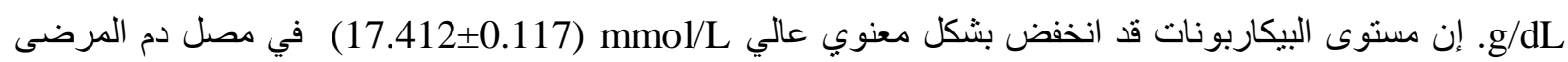




\section{Determination of IL-35, PTH, Ferritin and Other biochemical. Parameters in sera of Iraqi Men with chronic kidney failure}

\section{Rasha Zuhair Jasim and Samira Muajed Yaseen}

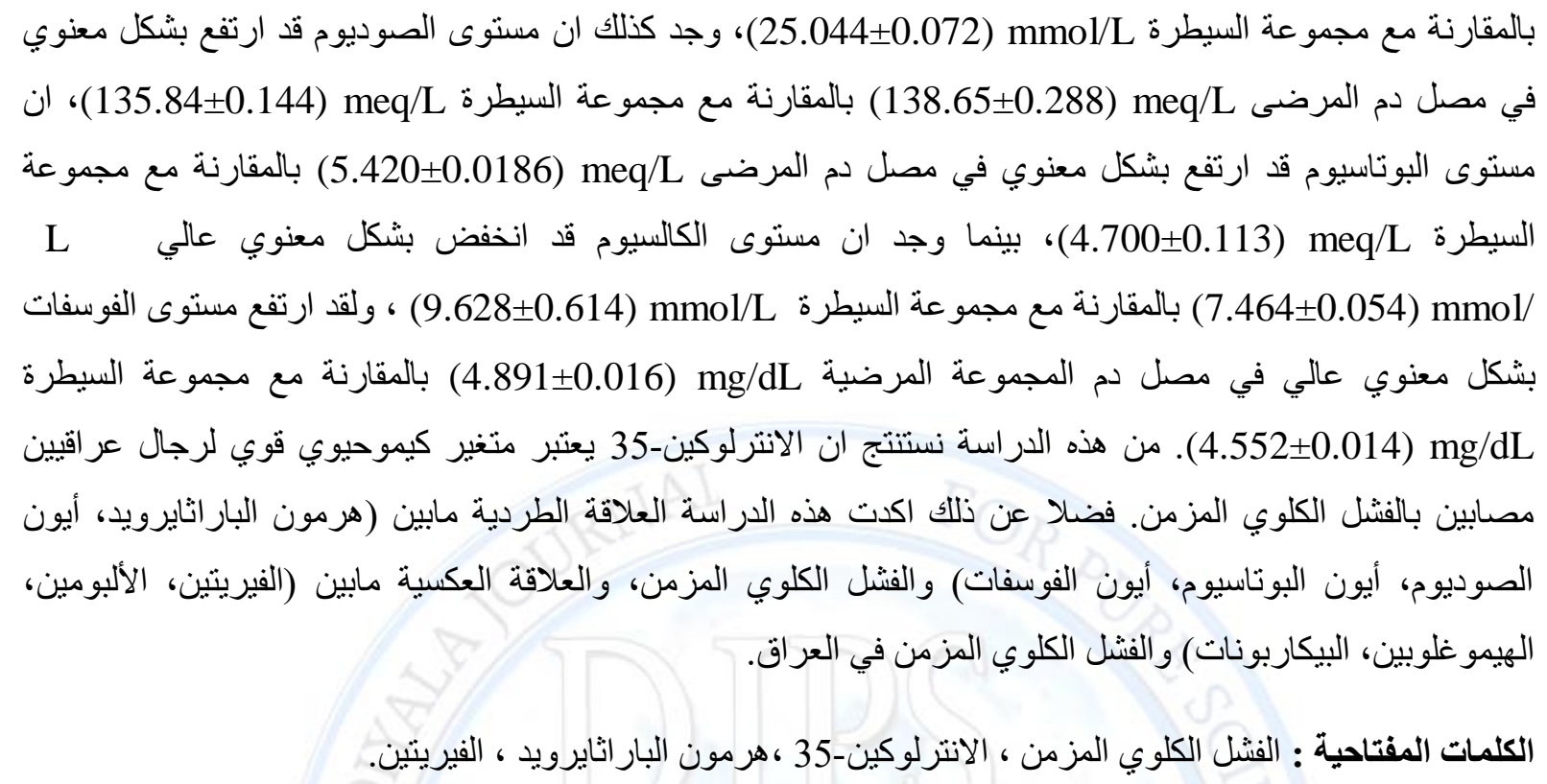

\section{Introduction}

The major function of the kidney is regulation of the blood composition and volume , removing the metabolic wastes by filtration to the urine, secretion of the final products of metabolism and the excess of electrolytes and controlling the acid/balance in the body $[1,2]$. Chronic kidney failure ( $\mathrm{CKF}$ ) is a progressive disease, generally is defined as the reduction of kidney function, this reduction is estimated by glomerular filtration rate (eGFR) $<60 \mathrm{~mL} / \mathrm{min}$ [2]. According to the global Burden of Disease 2010, chronic kidney disease now ranks as the $9^{\text {th }}$ cause of death [3]. As chronic kidney failure include a complex dysfunction in express including an interaction between the innate and adaptive immune system, in which immune activation (hypercytokinemia) coexist [4]. In the regards, IL-35 is an auto-immune suppressive and anti-inflammatory cytokine, it can suppress a variety of $\mathrm{T}$ cells including proinflmmatory Th1 and Th17 and probably dendritic cells [5]. Parathyroid hormone (PTH) is secreted by parathyroid gland to regulate calcium and phosphate levels in the blood flow and maintaining bone health, this hormone is eliminated mostly from the liver, kidneys and bones, [6]. PTH is a peptide hormone, composed of 84 amino acids, this hormone is necessary for regulation of blood calcium [6,7]. Ferritin is released by infiltrating leukocytes in response to 


\section{Determination of IL-35, PTH, Ferritin and Other biochemical. Parameters in sera of Iraqi Men with chronic kidney failure}

\section{Rasha Zuhair Jasim and Samira Muajed Yaseen}

acute and chronic infection. It has a crucial role in iron homeostasis since it binds and sequesters interacellular iron. It is a spherical shell with a central cavity where up to 4.500 atoms of iron oxidized and stored. About the chemical structure of ferritin, it is a multimer composed of $24 \mathrm{H}$ (heavy) and (light) subunits in variable proportions in different tissues. The two subunit are highly conserved during evolution, but only the $\mathrm{H}$ subunit has ferroxidase activity. [8]. On the other hand, hemoglobin is found exclusively in red blood cells (RBCs) where its main function is to transport oxygen $\left(\mathrm{O}_{2}\right)$ from the lungs to the capillaries of the tissues.In adults, it is composed of four polypeptide chain-two $\alpha$ chains and two $\beta$ chains held together by non covalent interactions [9]. Albumin is the most abundant protein in plasma or serum. Moreover, $60 \%$ of the total albumin is found in tissues and secretions [10]. It has important physiological functions; regulation colloidal osmotic pressure [11]. As a carrier protein, albumin plays an essential role in the binding of some drugs, in addition to endogenous and exogenous substances such as fatty acids, steroid hormones in the blood stream [12].Sodium and potassium are essential in maintaining cellular homeostasis and maintaining osmotic pressure, sodium cation are the major cations of the extracellular fluid, while potassium ions are the major cations of the interacellular fluid. Potassium and sodium ions are particularly important in the renal regulation of acid-base [12]. Interestingly, metabolic acidosis (reflected by a low serum bicarbonate) is a typical common complication of chronic kidney disease [13]. Calcium is a key nutrient necessary for many functions in human health. Calcium metabolism involves many biochemical compounds including proteins, phosphate and vitamin D [[14]. There is a crucial relationship between PTH and calcium level in plasma or serum [7]. Inorganic phosphate is required for cellular function and skeletal mineralization [15]. Maintenance of phosphate homeostasis centers in the regulation of phosphate handling by bone, intestine and kidney. 


\section{Determination of IL-35, PTH, Ferritin and Other biochemical. Parameters in sera of Iraqi Men with chronic kidney failure}

\section{Rasha Zuhair Jasim and Samira Muajed Yaseen}

\section{Material and methods}

In the present study, (30) man suffering from CKF with age in range (40-55) years were enrolled in this study. They have diagnosed by blood and urine tests and imaging tests (ultrasound). Patients study were newly diagnosed; they were not taken any treatment except some tablets related to hypertension. Patients group were compared with (30) healthy subjects as a control group (in the same range of age). Blood sampling and biochemical parameters measurement were performed in Al - Karama teaching Hospital in Baghdad ( except IL-35 which was determined in the private Al-Ghazalia Laboratory) from April to November 2015. Approximately, $(5 \mathrm{ml})$ of venous blood were collected from all subjects enrolled in this study, subsequently, serum was separated from blood cells by centrifugation at 4000 r.p.m. for (5-7) min. after separation, serum was kept frozen until analysis. IL-35 was determined by a quantitative sandwich enzyme linked immunosorbent assay (ELISA) technique. Antibody specific for IL-35 was precoated into a microplate accompanied with IL-35 kit, standard and samples were pipetted into the wells and immobilized antibody binds any IL-35 present. After removing any unbound substances, a biotin conjugated antibody specific for IL-35 was added to the wells. After washing, avidin conjugated Horseradish Peroxidase (HRP) was added to the wells and color develops in proportion to the amount of IL-35 bound in the initial step. The color development is stopped and the intensity of the color is measured. Parathyroid hormone was determined in ultrasound five needle aspirates, while ferritin level was measured by ion exchange and size exclusion chromatography, albumin level was determined, proposed for determination of human serum albumin using terbium-danofloxacin. Hemoglobin level was determined using high performance liquid chromatography. Bicarbonate level was determined by atomic absorption (flame) spectroscopy. Sodium and potassium levels were determined on the basis of Ion-selective electrode diluted. Calcium ion level was determined on the basis of Arsenazo [17]. This is based on the reaction of calcium with arsenazo (2,2'-[1,8-Dihydroxy-3,6-disulphonaphthlene-2,7-bisazo]-bisbenzenear-sonic acid) to form an intense purple colored complex. Phosphate ion levels were determined in 
Determination of IL-35, PTH, Ferritin and Other biochemical. Parameters in sera of Iraqi Men with chronic kidney failure

Rasha Zuhair Jasim and Samira Muajed Yaseen

serum by phosphomolybdate method [18]. this methods generally depends on developing a specific blue color of the phosphomolybdate complex in the presence of reducing agent (hydroguinone). Lastly, results were statistically expressed as mean \pm S.D, student T-test was applied for comparing the significance of difference between patient and control group, $\mathrm{P}$ refers to possibility whereby: $(\mathrm{P}<0.05),(\mathrm{P}<0.001)$ and $(\mathrm{P}>0.05)$ were respectively considered significant, highly significant and non-significant.

\section{$\underline{\text { Results }}$}

Table (1): Levels of IL-35, PTH, hemoglobin, ferritin and albumin and in sera of chronic kidney failure group and control group

\begin{tabular}{|c|c|c|c|}
\hline Parameter & $\begin{array}{c}\text { Control } \\
\text { Mean } \pm \text { S.D }\end{array}$ & $\begin{array}{c}\text { Patients } \\
\text { Mean } \pm \text { S.D }\end{array}$ & P value \\
\hline IL-35 $(\mathrm{pg} / \mathrm{mL})$ & $23.331 \pm 0.031$ & $35.038 \pm 0.025$ & H.S \\
\hline PTH $(\mathrm{pg} / \mathrm{mL})$ & $49.96 \pm 0.308$ & $235.032 \pm 3.841$ & H.S \\
\hline Hemoglobin $(\mathrm{g} / \mathrm{L})$ & $15.332 \pm 0.067$ & $9.696 \pm 0.056$ & H.S \\
\hline Ferritin $(\mathrm{ng} / \mathrm{mL})$ & $313.56 \pm 1.874$ & $164.068 \pm 7.818$ & H.S \\
\hline Albumin $(\mathrm{g} / \mathrm{dL})$ & $4.928 \pm 0.039$ & $3.000 \pm 0.020$ & H.S \\
\hline
\end{tabular}


Determination of IL-35, PTH, Ferritin and Other biochemical. Parameters in sera of Iraqi Men with chronic kidney failure

Rasha Zuhair Jasim and Samira Muajed Yaseen

Table (2): Levels of bicarbonate, sodium, potassium, calcium and phosphate ions in sera of chronic kidney failure group and control group.

\begin{tabular}{|c|c|c|c|}
\hline Parameter & $\begin{array}{c}\text { Control } \\
\text { Mean } \pm \text { S.D }\end{array}$ & $\begin{array}{c}\text { Patients } \\
\text { Mean } \pm \text { S.D }\end{array}$ & P value \\
\hline $\mathrm{HCO}_{3}{ }^{-}(\mathrm{mmol} / \mathrm{L})$ & $25.044 \pm 0.072$ & $17.412 \pm 0.117$ & H.S \\
\hline $\mathrm{Na}^{+}(\mathrm{meq} / \mathrm{L})$ & $135.84 \pm 0.144$ & $138.65 \pm 0.288$ & N.S \\
\hline $\mathrm{K}^{+}(\mathrm{meq} / \mathrm{L})$ & $4.700 \pm 0.113$ & $5.420 \pm 0.0186$ & H.S \\
\hline $\mathrm{Ca}^{2+}(\mathrm{mmol} / \mathrm{L})$ & $9.628 \pm 0.614$ & $7.464 \pm 0.054$ & H.S \\
\hline $\mathrm{PO}_{4}{ }^{2-}(\mathrm{mg} / \mathrm{dL})$ & $4.552 \pm 0.014$ & $4.891 \pm 0.016$ & $\mathrm{~S}$ \\
\hline
\end{tabular}

H.S: Highly significant, S: Significant, N.S: non- significant

Table (3): Correlation coefficients (r) between IL35 and other studied parameters.

\begin{tabular}{|c|c|}
\hline Correlated parameters & Correlation coefficient (r) \\
\hline IL-35 vs PTH & +0.007191 \\
\hline IL-35 vs Hemoglobin & -0.03377 \\
\hline IL-35 vs Ferrtin & -0.03407 \\
\hline IL-35 vs Albumin & -0.0593 \\
\hline IL-35 vs $\mathrm{HCO}_{3}{ }^{-}$ & -0.01055 \\
\hline IL-35 vs Na ${ }^{+}$ & +0.32388 \\
\hline IL-35 vs K & +0.034307 \\
\hline IL-35 vs Ca & \\
\hline IL-35 vs PO4 & \\
\hline
\end{tabular}


Determination of IL-35, PTH, Ferritin and Other biochemical. Parameters in sera of Iraqi Men with chronic kidney failure

Rasha Zuhair Jasim and Samira Muajed Yaseen

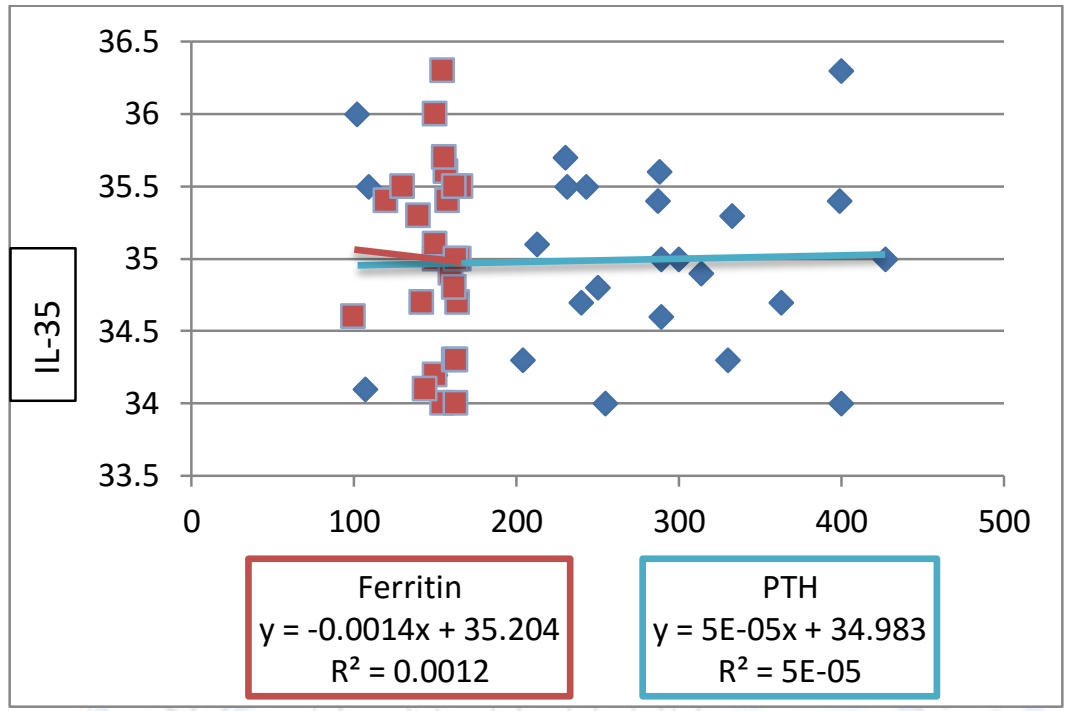

Fig (1): IL35vs Ferritin and IL-35 vs PTH correlations

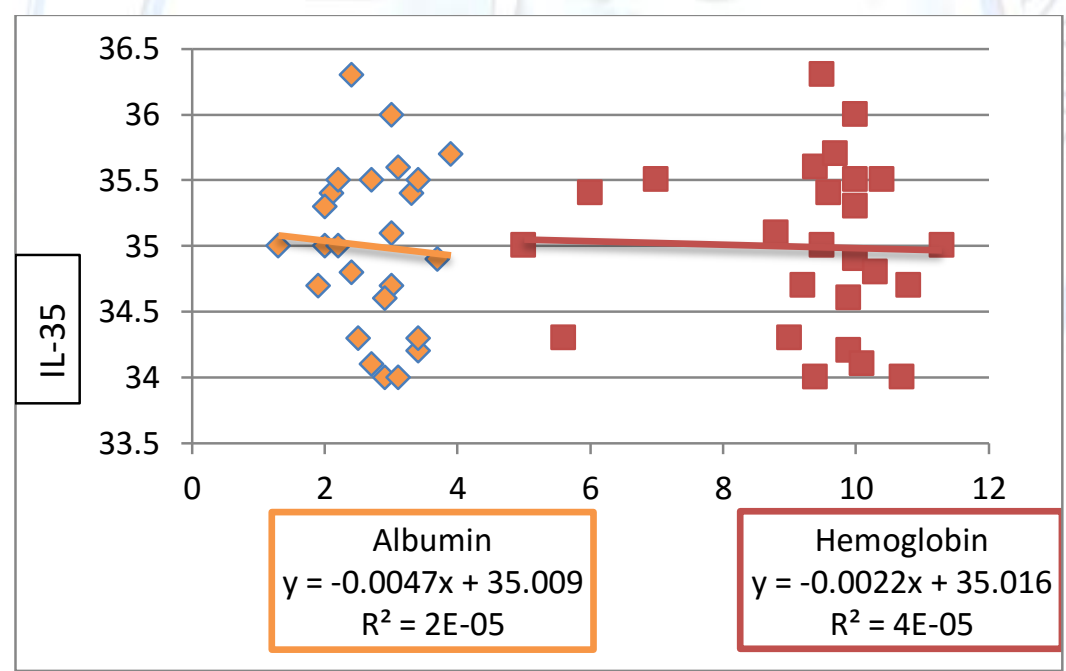

Fig (2): IL35vs Albumin and IL-35 vs Hemoglobin correlations 
Determination of IL-35, PTH, Ferritin and Other biochemical. Parameters in sera of Iraqi Men with chronic kidney failure

Rasha Zuhair Jasim and Samira Muajed Yaseen

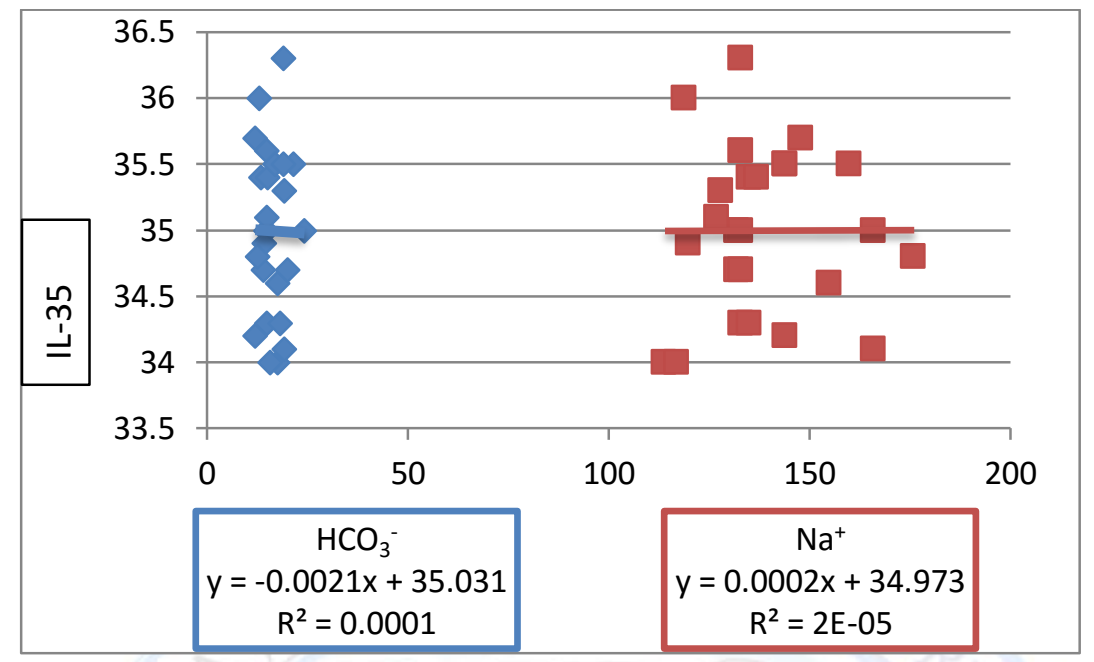

Fig (3): IL35vs $\mathrm{HCO3}^{2-}$ and IL-35 vs $\mathrm{Na}^{+}$correlations

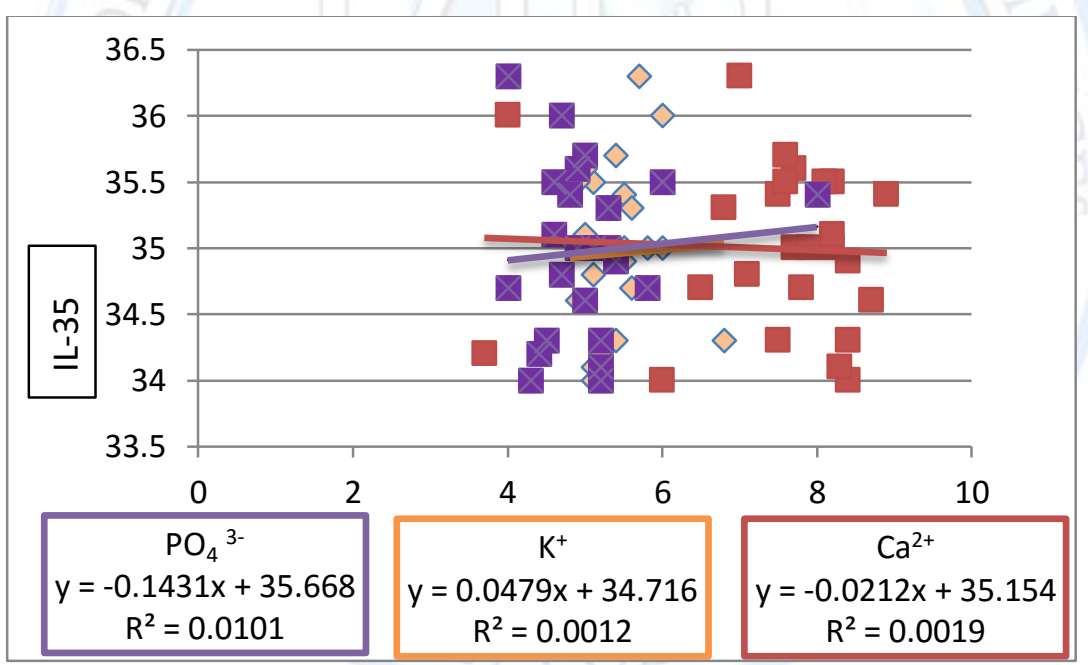

Fig (4): IL35vs PO43- , IL-35 vs K+and IL35vs Ca2+ correlations 


\section{Determination of IL-35, PTH, Ferritin and Other biochemical. Parameters in sera of Iraqi Men with chronic kidney failure}

\section{Rasha Zuhair Jasim and Samira Muajed Yaseen}

Results of table (1) have revealed that IL-35 was highly significant increased $(\mathrm{P}<0.001)$ in sera of CKF patients $(35.038 \pm 0.025) \mathrm{pg} / \mathrm{ml}$ compared with healthy control group (23.331 \pm 0.031$) \mathrm{pg} / \mathrm{ml}$, as well, PTH was highly significant increase $(\mathrm{P}<0.001)$ in sera of CKF patients $(235.032 \pm 3.841) \mathrm{pg} / \mathrm{ml}$ compared with healthy control group (49.96 \pm 0.308$)$ $\mathrm{pg} / \mathrm{ml}$.Conversely, ferritin level was highly significant decrease $(\mathrm{P}<0.001)$ in sera of chronic kidney failure $(164.068 \pm 7.818) \mathrm{ng} / \mathrm{ml}$ compared with healthy control group $(313.56 \pm 1.874)$ $\mathrm{ng} / \mathrm{ml}$. similarly, albumin level was highly significant decreased $(\mathrm{P}<0.001)$ in sera of CKD $(3.000 \pm 0.020) \mathrm{g} / \mathrm{dl}$ in comparison with healthy control group $(4.928 \pm 0.039) \mathrm{g} / \mathrm{dl}$. Furthermore, hemoglobin level was highly significant decreased $(\mathrm{P}<0.001)$ in sera of same patients $(9.696 \pm 0.056) \mathrm{g} / \mathrm{L}$ compared with healthy control group $(15.332 \pm 0.067) \mathrm{g} / \mathrm{L}$. Results of table (2) have reported that bicarbonate level was highly significant decreased $(\mathrm{P}<0.001)$ in sera of chronic kidney failure patients $(17.412 \pm 0.117) \mathrm{mmol} / \mathrm{L}$ compared with healthy control group $(25.044 \pm 0.072) \mathrm{mmol} / \mathrm{L}$. On the other hand, sodium level was none significantly increased ( $p>0.05)$ in sera of chronic kidney failure patients $(138.65 \pm 0.288)$ meq/L compared with healthy control group $(135.84 \pm 0.144)$ meq/L. Further, potassium level was highly significant increased $(\mathrm{P}<0.001)$ in sera of same patients $(5.420 \pm 0.0186) \mathrm{mmol} / \mathrm{L}$ in comparison with control group $(4.700 \pm 0.113) \mathrm{mmol} / \mathrm{L}$, while calcium level was highly significant decreased $(\mathrm{P}<0.001)$ in sera of patients $(7.464 \pm 0.054) \mathrm{mmol} / \mathrm{L}$ compared with control group $(9.628 \pm 0.614) \mathrm{mmol} / \mathrm{L}$, phosphate level was significantly increase $(\mathrm{P}<0.001)$ in sera of patients $(4.891 \pm 0.016) \mathrm{mg} / \mathrm{dL}$ compared with healthy subjects $(4.552 \pm 0.014) \mathrm{mg} / \mathrm{dL}$. Finally, table (3) explains positive and negative correlation coefficients (r) between IL-35 and other studied parameters, figures from 1 to 4 show positive and negative relationships between IL-35 and the other studied parameters.

\section{$\underline{\text { Discussion }}$}

Broadly, alterations of the immune system in renal disease contribute a complex issue. In this regard, hypercytokinemia is a typical feature of kidney failure. Advanced stages of kidney disease give rise to various cytokine disturbances and to a state of hypercytokinemia.T helper 


\section{Determination of IL-35, PTH, Ferritin and Other biochemical. Parameters in sera of Iraqi Men with chronic kidney failure}

\section{Rasha Zuhair Jasim and Samira Muajed Yaseen}

lymphocytes play a crucial role in controlling the immune responses; these immune cells produce several cytokines [19]. A recent study has reported that IL-35 is produced by regulatory $\mathrm{T}$ cells to suppress autoimmune and inflammatory responses, in other words, to counteract the autoimmune attack [20]. Taken together, these explanations give a good support to the highly significant increase in IL-35 level in CKF patients compared with healthy control ( table 1). More recently, fibroblast growth factor-23 which increase in chronic kidney disease as a consequence of phosphorous retention, has been found to suppress calcitriol synthesis, leading to increase PTH level [21]. This study agreed with our results related to PTH (table 1). On the other hand, renal anemia due to iron restricted erythropoiesis in common condition associated with chronic kidney failure. When kidney are damaged, the secretion of erythropoietin deceased, resulting in renal anemia. Because iron is required for erythropoiesis, low iron stones may cause anemia. [22,23]. These suggestion reflect the highly significant decreased in hemoglobin level in patients enrolled in this study compared with control group. Another study has demonstrated mechanism of anemia in chronic kidney disease, patients suffering from this disease, particularly hemodialysis patients have impaired dietary iron absorption [24]. Interestingly, serum ferritin is one of the main markers of iron status [25]. At this point, ferritin synthesis is induced by administrating iron [26]. For the reasons mentioned above, ferritin was highly significant decreased in sera of patients. As well, a previous study has revealed that catabolism rate of albumin was 3-times increased in patients suffering from uremia [27]. This study gives a good evidence to our results related to albumin level. Metabolic acidosis is more common associated with the development of chronic kidney disease [28,29]. This case is a common complication associated with progressive loss of kidney function [29]. Decreasing kidney function cause progressively retention of hydrogen ions, increase in kidney intestinal activity and low plasma bicarbonate $[29,30]$. Those suggestions agree with our results related to bicarbonate (table 2). Anyway, metabolic acidosis is a predictor of kidney disease progression [30]. A study has suggested that chronic kidney disease is associated with sodium load [31]. Another study has reported that the mechanism of hypertension associated with chronic kidney failure is likely to be 


\section{Determination of IL-35, PTH, Ferritin and Other biochemical. Parameters in sera of Iraqi Men with chronic kidney failure}

\section{Rasha Zuhair Jasim and Samira Muajed Yaseen}

related to the relative inability of infected kidney to excrete sodium. [32] those two studies agree with our results related to sodium level in table (2). Moreover, a recent study has indicated that $95 \%$ of filtered sodium ions were reabsorbed in chronic kidney disease. [33]. In some cases with chronic kidney diseases, the kidneys may not remove extra potassium from the blood [34]. Interestingly, mechanism of renal excretion of potassium ions is compromised in patients with chronic kidney disease. Anyway, it might increases along with deteriorating renal function. Subsequently, elevated potassium ion level might be itself stimulated potassium ions excretion. [35]. Another recent study has linked between chronic kidney disease and hyperkalemia an elevated concentration of the electrolyte potassium in the blood) [2]. In chronic kidney disease, a reduction in calcium receptors expression in vascular smooth muscle cells (VSMS) was shown [36]. Consequently, this decrease in calcium receptors leads to a decrease in calcium level in serum and agree with our results (table 2). On the other hand, a previous study has reported an inverse relationship between parathyroid hormone and calcium level in chronic kidney disease, parathyroid glands released higher concentrations of PTH in response to low level of calcium blood [37]. This study strongly supported our results and links between PTH level in (table 1) and Ca level in (table 2). In this regard, PTH is the most important hormone that contributes to the regulation of phosphate in the kidney [38]. It has been shown that higher level of serum phosphate adjusted for creatinine clearance was associated with mortality in chronic kidney disease [39]. Phosphate homeostasis is maintained by the hormonal control of its transport in intestine, bone and kidney. [40]. This mechanism clearly explains the higher level of phosphate in chronic kidney disease in comparison with healthy control (table 2). Furthermore, (table 3) and figures from 1 to 4 have a good indication to the results of (table 1) and( table 2), revealing that $\left(\mathrm{PTH}, \mathrm{Na}^{+}, \mathrm{K}^{+}, \mathrm{PO}_{4}{ }^{3-}\right)$ are positively correlated with CKF because all these parameters have (+r) values with IL-35 and (hemoglobin, Ferritin, albumin, $\mathrm{HCO}_{3}{ }^{-}, \mathrm{Ca}^{2+}$ ) are negatively correlated with $\mathrm{CKF}$ because all these have (-r) values with IL-35. 
Determination of IL-35, PTH, Ferritin and Other biochemical. Parameters in sera of Iraqi Men with chronic kidney failure

Rasha Zuhair Jasim and Samira Muajed Yaseen

\section{$\underline{\text { Conclusion }}$}

1. IL-35 is a good (up to date) biochemical marker for CKF in Iraqi men.

2. This study highlights the positive relation between (PTH, Na+, $\mathrm{K}+, \mathrm{PO} 42-)$ and $\mathrm{CKF}$ and the negative relation between (hemoglobin, Ferritin, albumin, $\mathrm{HCO}_{-}, \mathrm{Ca} 2+$ ) and $\mathrm{CKF}$ in Iraq.

\section{$\underline{\text { References }}$}

1. Tzanakaki, E.; Boudouri, V.; Stavropoulou, A.; Stylianou, K.; Rovithis, M. and Zidianakis, Z. Causes and complications of chronic kidney disease in patients on dialysis; Health Science Journalk. 2014, 8(3): 343-347.

2. An Overview Guide for Dietitians. Chronic Kidney Disease (CKD) and Diet: Assesment, Management and Treatment; National Kidney Disease Education Program, NTH Publication.2013, No.15-7406.

3. Akpan, E.E.; Ekrikpo, U.E.; Cronic Kidney failure: knowledge of kidney disease perception of causes and symptomatology in Uyo, Nigeria; Open Journal of Nephrology. 2015, 5, 91-97.

4. Hauser, A.B.; Stingher, A.E.; Kato, S. Bucharles, S.; Aita, C.; Yuzawa, Y.; Pecoits-Filho, R. Characteristics and causes of immune dysfunction related to uremia and analysis; Peritoneal Dialysis International. 2007, 28(3) 183-187.

5. Turnis, M.E.; Sawant, D.V.; Szymczak-Workman, A.L.; Andrewa, L.P.; Delgoffe, G.M.; Workman, C.J.; Vignali, D.A. Interleukin-35 Limits Anti-Tumor Immunity; Epub Immunity. 2016, 414(2): 316-329.

6. Dumitras, M.; Strambu, V.; Iorga, C.; Benulescu, I.; Popa, F. Parathyroid hormone between limits and possibilities in secondary hyperparathyroidism ; Human and Veternity Medicine.2015, 76: 84-88. 


\section{Determination of IL-35, PTH, Ferritin and Other biochemical. Parameters in} sera of Iraqi Men with chronic kidney failure

\section{Rasha Zuhair Jasim and Samira Muajed Yaseen}

7. Monis, E.L.; Mannstadt, M. Hypoparathyroidism-disease update and emrging treatments; Annalesd' Endocrinologie. 2015, 7(2): 86-88

8. Nandini, M.D.; Shetty, H.V.; Pupakala, B.V.; Usha, S.M.; Priyadarshini, K.S.; Manjula, H.S.; Victoria, K. Study of Serum Ferritin Levels in Preterm labori, International Journal of Recent Trends in Science and Technology. 2015, 4(2), 477-480.

9. Harvet,R. and Ferrier, D. Lippicott's Illustrated Reviews Biochemistry; Fifth edition; Library of Congress Cataloging-in-Publication Data. 2011, Unit 1, Chapter 3.

10. Chen, Y.; Wang, H.; Niu, Q.; Ye, d.; Liang, G. Binding between Saikosponin C and Human Serum Albumin by Fluorescence Spectroscopy and Molecular Docking; Molecules. 2016,21(153):1-15.

11. Yang, F. Zhang, Y.; Liang, H. Interactive Association of Drugs, Binding to Human Serum Albumin; Int. J. Mol. Sc. 2014, 15: 3580-3590.

12. Pohl, H.R.; Wheel, J.S.; Murra, H.E. Sodium and Potassium in Health and Disease; Agency for toxic Substances and Disease Registry.2013; chapter 2.

13. Basile, C.; Rossi, L.; Lomonte, C. The choice of dialysate bicarbonate: do different concentrations make a differences?; Kidney International. 2016, 0.010. http//dx.doi.org/10.1016/j.kint

14. Beto, J.A. The role of calcium in human aging; The Korean Society of Clinical Nutrition .2015, http://e-cur.org.

15. Blaho, V.A; Hla. An update on the biology of sphingos in phosphate receptors; Lipid Research. 2014, 55: 1596-1608.

16. Le derer, E.D. Regulation of serum phosphate; Physiology.2014, 592 (18): 3948-3995.

17. Boonyasit , Y. ; Chinvongumorn , C. ; Chailapakul, O. and Laiwattanapaisal, W. Simple spectrophotometric sequential injection analysis system for determination of serum calcium ; American Journal of Analytical Chemistry. 2012 , (3):131-137.

18. Pradhan, S. and Prkhrel, M. Spectrophotometric determination of phosphate in sugarcane juice fertilizer, detergent and water samples by molybdenum blue method ; Scientific world. 2013,11(11):58-62. 
Determination of IL-35, PTH, Ferritin and Other biochemical. Parameters in sera of Iraqi Men with chronic kidney failure

Rasha Zuhair Jasim and Samira Muajed Yaseen

19. Kato, S.; Chmielewski, M.; Honda, H.; Pecoits-Filho, R.; Matsuo, S.; $\quad$ Yuzawa, Y.; Tranaeus, A.; Stenvinkel, P. and Lindholm, B. Aspects of Immune; The American Society of Nephrology. 2008, (3):1526-1533.

20. Singh, K.; Kadesjo, E.; Lindroos, J.; Hjort, M.; Lundberg, M.; Espes, D.; Carlsson, P. and Sandler, S.; Thorvaldson, L.I. Interleukin-35 administration counteracts established murine type 1 diabetes-possible involvement of regulatory T cells; Scientific Reports. 2015, 5: 12633 IDOI:10.1038/srep12633.

21. National Kidney Foundation Parathyroid Hormone and Secondary Hyperparathyroidism in Chronic Kidney disease; AWGEN Nephrolog. 2012, www.kidney.org800.622.9010.

22. Rerambiah, L.K.; Rerabiah, L.E.; Etomba, A.M.; Mouguiama, R.M.; Issanga, P.; Biyoghe, A.; Batchilili, B. Assembe, S.A.; Siawaga, J.F. Blood Transfusion, Serum Ferritin, and iron in jemodialysis patients in Africa; Blood Transfusion .2015, ID 720389, http $>/ / d x . d o i . o r g / 10.1155 / 720389$.

23. National Kidney disease education Program. Making Sence of CKD: A Concise Guide for managing Chronic Kidney disease in the primary care setting; A program of the National Institute of health. 2014, NIH Publication No.14-7989.

24. Babitt, J.L.; Lin, H.Y. Mechanism of anemia in CKD; Am Soc Nephrol. 2012, 23: 1631 1634.

25. Reddy, G.C.; Devaki, R.; Rao, P. Iron indices in patients with functional anemia in chronic kidney disease; IFCC .2013, 24(3-4).

26. Summary of a report on assessment of the iron nutritional states of the United States population. Experet Scientific Working Group; Clinical Nutrition. 1985, 42: 1318-1330.

27. Buehler, B.A. Hereditary Disorders of Albumin Synthesis; Annals of Clinical and laboratory Science.1978, 283(4): 283-286. 


\section{Determination of IL-35, PTH, Ferritin and Other biochemical. Parameters in} sera of Iraqi Men with chronic kidney failure

\section{Rasha Zuhair Jasim and Samira Muajed Yaseen}

28. Withman, M.D.; Band, M.M.; Littleford, R.C.; Avenell, A.; Soiza, R.L.; McMurdo, M.; Sumukadas, D.; Ogston, S.; Lamb, E.J.; Hampson, G.; NcNamee, P. Dose oral sodium bicarbonate therapy improve function and quality of life in older patients with chronic kidney disease and low-grade acidosis (the BiCARB trail) study protocol for a randomized controlled trial; Trials. 2015, 16: 326, DOI. 1186/s 13063-015-0843-6.

29. Kovesdy, C. Metabolic acidosis and kidney disease: does bicarbonate therapy slow the progression of CKD; Nephrol Dial Transplant. 2012, 27: 30-56-3062.

30. Dober, M.; Yang, W.; Pan, Q.; Appel, L.; Bellovich, K.; Chen, J.; Feldman, H.; Fischer, M.J.; Ham, L.; Hostetter, T.; Jaar, B.; Scialla, J.; Eolf, M.; Rahman, M. Persistance high serum bicarbonate abd the risk of heart failure in patients with chronic renal insufficiency cohort 9CRIC) study, American Heart Association. 2015, 4: e001599ndoi 10.1161/JAHA.114.001599

31. Levin, N.W.; Kotanko, P.; Eckardth, K.; Kasiske, B.L.; Redon, J.; Wheeler, D.; Zoccali, C.; London, G. Blood pressure in chronic kidney disease stage: Improving Global Outcome Controversies Conference; International Society of Nephrology.2009, htpp://www.kidney-International/org.

32. Koomans, H.; Roos, J.; Mees, E. and Delawi, I. Sodium Balance in Renal Failure: a comparison of patients with normal subjects under extremes of sodium intakes; The Nerther-land. 1985, 7(5): 714-721.

33. Sterns, R.; Rajas, M.; Berustein, P. Chennupati, S. Ion exchange Resin for the treatment of hyperkalemia: Are the Safe and Effective?; Am Soc Nephrol. 2010, 21: 733-735.

34. National Kidney disease education program. Potassium; U.S. Department of health. 2011, NIH Publication No.11-7407.

35. Hsieh, M.H.; Wu, I.W.; Lee, C.; Wang, S.; Wu, M. High serum potassium level associated with late stage chronic kidney disease; Change Gung Med. 2011, 34: 418-425.

36. Barle, A.B. Calcium and phosphate metabolism; Annual Review of Physiology.1974, 36(1): 361-390. 
Determination of IL-35, PTH, Ferritin and Other biochemical. Parameters in sera of Iraqi Men with chronic kidney failure

Rasha Zuhair Jasim and Samira Muajed Yaseen

37. U.S. Department of health and human services. National Kidney and Urologic Diseases Information Clearinghouse; National Institute of health. 2009, NIH Publication No.094630.

38. Langman, C.B. and Cannata-Andia, J.B. Calcium in chronic kidney disease: Myths and Realities; Am Soc Nephrol.2010, 5: s1-s2, doi:10.2215/CJN.06140809.

39. Eddington, H.; Hoefield, R.; Sinha, S.; Chrysochou, C. Serum Phosphate and Mortality in Patients with Chronic Kidney Disease; Am Soc Nephrol.2010, 5: 2251-2257.

40. Oliveia, R.B.; Okazak, H.; Stinghem A.E.; Drueke, T.; Massay, Z.; Jorgetti, V. Vascular Calcification in chronic kidney disease: a review; Bras Nefrol.2013, 35(2): 147-161. 